\title{
Illegal cigarette sales to children in South Australia
}

\author{
Melanie Wakefield, John Carrangis, David Wilson, Christopher Reynolds
}

\begin{abstract}
Objective To assess how easily cigarettes could be purchased by children from retail stores and vending machines in South Australia.

Design Ten children aged between 12 and 14 years visited 98 stores and 29 vending machines with the intention of purchasing cigarettes.

Main outcome measures Percentage of successful attempts to purchase cigarettes.

Results Children succeeded in purchasing cigarettes at nearly half of the stores and all of the vending machines. This occurred despite the fact that approved sales to minors notices were displayed at almost two thirds of the stores and three quarters of the vending machines.

Conclusion More effective retail controls are required to prevent the relatively easy purchase of cigarettes by children in South Australia.
\end{abstract}

\section{Introduction}

The majority of new smokers are drawn from the ranks of children, at a time when they are considered ill equipped to make lifelong decisions. Rates of smoking in children of 15 years approximate to those in adults, although most adults smoke daily and more heavily. ${ }^{1}$ Thus, as Hill et al relate, it seems clear that "by the time children are ready to leave school, the stage is set for the rapid acquisition of adult smoking prevalence and consumption levels." Although it is now well established that tobacco smoking is addictive, ${ }^{2}$ children fre-

Behavioural

Epidemiology unit, Epidemiology Branch, South Australian Health Commission, PO Box 6 Rundle Mall, South Australia 5000, Australia M Wakefield

Non-Smokers' Movement, PO Box 455, Eastwood, South Australia 5063

J Carrangis

Department of Community Medicine, University of Adelaide, GPO Box 498, Adelaide, South Australia 5001

C Reynolds

Correspondence to: $\mathrm{Ms}$ Wakefield. smoking in childhood and adolescence. However, faced with the powerful marketing and promotion of cigarettes by the tobacco industry, efforts to educate children about the dangers of tobacco use may be compromised. Even where there are controls on cigarette advertising and promotion, there is a concern that the ease with which children are able to obtain cigarettes may limit the efficacy and credibility of educational messages.

There are few consumer items other than tobacco that can be purchased in so many different locations at any time of the day or week. Availability is a key element in the successful marketing of any product and is a crucial factor in both creating and maintaining addiction to cigarettes. The link between accessibility and consumption has been convincingly shown in the case of alcohol ${ }^{8}$ and, as Kaplan concludes, ${ }^{9}$ the more available drugs are "the higher the rate of use-and of addiction." Kaplan cites many examples to confirm this principle, arguing that the ready availability of tobacco increases the amount smoked by current smokers and makes it much more difficult for them to stop and easier for children to start.

For most of this century South Australia has had legislation prohibiting the sale or supply of cigarettes to children aged under 16 years, with the maximum penalty having been increased to $\$ A 1000$ in 1986 (section 11, South Australian Tobacco Products Act 1986). In addition, there is a requirement that retailers display an approved warning notice informing consumers of this law. Other Australian states vary according to the legal age (in Western Australia and New South Wales the legal age is 18 years) and the penalty attracted by infringement (in Western Australia the maximum penalty was recently increased to $\$ \mathrm{~A} 5000$ for an individual and $\$ A 20000$ for a corporation; in New South Wales the penalty is now $\$ A 5000$ ). There is no Australian state which prohibits the possession of cigarettes by children.

Although these laws are well intentioned, observation of the large number of under age regular smokers suggests that they may be of limited utility in reducing the access of children to tobacco, despite the fact that a programme of education of retailers has been undertaken in at least two states, South Australia and Victoria, clearly articulating the requirements of the legislation and its maximum penalty for infringement. This study therefore sought to assess formally the ease with which children were able to purchase cigarettes by over the counter sales and vending machines.

The methods guiding this survey were based on those in similar studies in the United States in which children tried to purchase cigarettes from a variety of different retail outlets. ${ }^{1011}$

For over the counter sales a random sample of 98 tobacco retail outlets in metropolitan 
Adelaide was selected from the telephone directory using a table of random numbers. The sample included delicatessens (45), petrol stations (16), supermarkets (23), tobacconists (2), shops selling wines and spirits (6), and newsagents (6), with proportionate representation according to their distribution in the marketplace. This sample size was sufficient to provide a reliable estimate of the success rate of attempted cigarette purchase by children. Based on an estimate that $50 \%$ of purchase attempts at a total of 1935 of these types of retail outlets listed in the Adelaide metropolitan area telephone book would be successful and with the $95 \%$ confidence interval set at $40 \%$ to $60 \%$, the required sample size for a simple random sample was $91 .^{12}$

With the consent of their parents four boys and six girls, aged between 12 and 14 years, visited these locations in January 1991 to attempt to purchase cigarettes. The children were invited to be involved in the study through their participation in a youth group, coordinated by one of the authors (JC). The children were therefore not randomly selected: however, none of these children were regular smokers and no attempt was made to recruit children who looked older than their chronological age.

Retail outlets involving over the counter attempts were grouped into convenient geographical areas and assigned to eight of the children. Only one purchase attempt was made at each retail outlet. Children were driven to each preselected retail outlet by an adult, who remained in the car out of view of the retailer. The child entered the store, approached the counter, and asked the retailer for a packet of cigarettes (boys asked for Peter Fackson and girls for Alpine). The children were instructed to be honest about their age if the retailer asked, thus allowing an opportunity for a sale not to be made. If a child was sold a packet of cigarettes, he or she immediately left the store and returned to the car.

In addition to whether the purchase attempt was successful, the child also reported on the sex and approximate age of the retailer $(<30$, $\geqslant 30$ ), whether other customers were present in the store, and whether the child was asked for his or her age or for whom the cigarettes were intended. After the purchase attempt the supervising adult entered the store to determine whether an approved warning sign about sales to children was displayed.

For vending machine sales a sample of 29 retail outlets in metropolitan Adelaide was randomly selected from the telephone directory. Purchase attempts were assigned by convenient geographical area to two of the boys who had participated in the over the counter component of the study (aged 12 and 14) and two girls who had not been involved previously (aged 13 and 14). The sample included hotels (15), recreation centres (6), restaurants and cafes (5), and transport stations (3). Each preselected retail outlet was telephoned several days before the purchases being attempted to ascertain whether a vending machine was on the premises. Replacement
Success rate of children's attempts to buy cigarettes in South Australia by type of retail outlet

\begin{tabular}{lcc}
\hline \multicolumn{1}{c}{ Retail outlet } & $\begin{array}{c}\text { No of } \\
\text { attempts }\end{array}$ & $\begin{array}{c}\text { No }(\%) \\
\text { of successes }\end{array}$ \\
\hline $\begin{array}{l}\text { Over the counter sales: } \\
\text { Delicatessen }\end{array}$ & 45 & $18(40)$ \\
Supermarket & 23 & $13(57)$ \\
Petrol station & 16 & $10(63)$ \\
Newsagency & 6 & $4(57)$ \\
Tobacconist & 2 & - \\
Shops selling wines and spirits & 6 & - \\
\hline Total & 98 & $45(46)$ \\
\hline Vending machines & 29 & $29(100)$ \\
\hline
\end{tabular}

was made for any retail outlet that did not possess a vending machine.

\section{Results}

OVER THE COUNTER SALES

Cigarettes were purchased by children from $45(46 \%)$ of the 98 retail outlets that sold tobacco over the counter. Purchase success varied from $67 \%$ at newsagencies to $40 \%$ at delicatessens, although these differences were not significant. Children were refused purchase at all tobacconists and shops selling wines and spirits. Where children were successful in purchasing cigarettes, they were not asked their age or for whom the cigarettes were intended. Of the 53 cases when children were refused sale, $83 \%$ were asked their age and $17 \%$ were asked for whom the cigarettes were intended (table).

Only $63.3 \%$ of retail outlets displayed the warning notice about sales to children. However, purchase success was unrelated to whether the sign was displayed. The presence of other people in the store and the sex and age of the vendor made no difference to whether a child was sold cigarettes.

In this study older children had a higher purchase success, with $56.9 \%$ of attempts by 14 year olds being successful, compared with $15.4 \%$ of 12 year olds $\left(\chi_{1}^{2}=11 \cdot 7, \mathrm{p}=0.0006\right)$. Sex was also related to purchase success, with $25.0 \%$ of attempts by boys and $69.6 \%$ of attempts by girls resulting in success $\left(\chi_{1}^{2}=\right.$ $17 \cdot 8, \mathrm{p}=0.02$ ).

\section{VENDING MACHINES}

Cigarettes were purchased from all of the 29 vending machines by the children. Irrespective of where vending machines were located - in public places or in places with restricted access to children - purchase was possible on every occasion it was attempted. In all, $21(72.4 \%)$ vending machines were posted with approved warning notices about sales to children.

\section{Discussion}

This survey confirms that children are able to purchase cigarettes, despite the existence of legislation aimed at preventing this from occurring. In almost one out of every two attempts children were able to purchase cigarettes successfully over the counter. From their own experience and that of their friends, 
the children involved in the survey believed that this success rate would probably have been higher if they had concealed their actual age or had indicated that the cigarettes were for a parent. Furthermore, although many of the cigarette vending machines in this survey were situated in places with traditionally restricted access to children, such as hotel bars, children were able to purchase cigarettes at these locations without hindrance on every occasion that they tried.

Other data from South Australia show that many children bought their first packet of cigarettes when they were as young as 8 years of age. ${ }^{13}$ Furthermore, recent South Australian figures indicate that, among schoolchildren aged 12 and 15 years, more than a third of those who smoked cigarettes in the previous week had bought their own cigarettes (B Devenish-Meares et al, unpublished report).

Given the total refusal by specialist tobacconists and shops selling wines and spirits to make sales to children, there is a strong argument to suggest that the sales to children requirements may be enforced more effectively if the places at which tobacco was sold were restricted to these specialist outlets. Such a move would be in keeping with other restrictions on the sale of toxic or dangerous products, most obviously alcohol, but also poisons and prescription drugs, for whose sale the law imposes responsibilities in exchange for the right to sell these products. Though we acknowledge the political difficulties associated with removing cigarettes from retail outlets such as delicatessens, we note that these outlets show a significant failure to comply with their legal obligations.

In considering action to remedy this situation, it is important to acknowledge that there are considerable practical difficulties in enforcing the sales to children legislation. ${ }^{14}$ Specifically, successful prosecution requires the evidence of an independent person, such as an adult actually present at the sale who is also sufficiently motivated to report the matter to the authorities. Prosecution is also time consuming and laborious, reflected by the fact that fewer than five prosecutions have been made in South Australia in the past five years (South Australia Health Commission, unpublished records).

Nearly two thirds of retail outlets displayed a sign warning that the sale of cigarettes to children was illegal, so that, by implication, these vendors must be aware of the legislation. Furthermore, purchase success was not related to whether vendors displayed the sign, clearly suggesting that awareness of the existing legislation is not a sufficient deterrent for retailers.

Several public health authorities in the United States have proposed elements of a "model law" to reduce the illegal sale of cigarettes to children. ${ }^{1516}$ Though some of these options may not be appropriate in an Australian context, others may be worthy of consideration. Some of these elements include : increased maximum penalties, in line with licensing provisions for wines and spirits (in
South Australia, this would involve a 15-fold increase in the penalty); an increase in the legal age of purchase to at least 19 years, the intention being to make all secondary school attenders minors for the purpose of the age of sale law; banning cigarette vending machines; introducing the use of citations for breaches that is, an expiation notice or "on the spot" fine, allowing the alleged offender to pay a specified sum of money to the enforcement agency in lieu of court proceedings; authorising use of a photo identification card by those aged 18 years or more which would be considered proof of age and could be required to be shown to vendors should they be unsure of the age of a purchaser; increasing the licence fee and using a proportion of it to fund the use of local government environmental health officers for increased surveillance and enforcement; and increased enforcement of the requirement to post an approved sign stating that sales to children are illegal.

Recent research on the prevention of smoking has been based on a developmental model of smoking acquisition, suggesting that young people can be classified into noncontemplators, contemplators, experimenters, occasional users, or regular users of tobacco. ${ }^{17}$ Although very motivated children who wish to purchase tobacco will probably find some way to do so, it is reasonable to expect that an increased degree of difficulty in obtaining cigarettes may contribute to an interruption of this process among some children, making occasional use and eventual addiction less likely.$^{18}$ Indeed, studies of restrictive smoking policies in schools have suggested that by making smoking inconvenient, the probability of regular tobacco use is reduced as children age into adolescence ${ }^{1920}$ or is at least postponed until adulthood.$^{21}$ Furthermore, recent studies have documented a decrease in the rates of cigarette experimentation among adolescents after increased enforcement and more certain, harsher penalties for underage cigarette sales decreased the likelihood of children being able to purchase cigarettes. ${ }^{2223}$

This study confirms the need to review existing means of preventing sales of cigarettes to children. Such a review is now timely, given the increasing prominence of point of sale tobacco advertising in Australia, as advertising and promotion through the mass media become restricted by other recent legislative controls. The extent of point of sale advertising can often limit the availability of space to adequately display mandatory signs about illegal sales of cigarettes to children. ${ }^{24} \mathrm{Com}$ prehensive approaches to preventing cigarette sales to children might also consider the need to limit point of sale advertising, so that tobacco control signage is made more salient.

We acknowledge the assistance of the following children in conducting this research project: Ben Carrangis (aged 12), Kirsty Lott (12), Grant Walsh (12), Jessica Wilkins (12), Emma Pearson (13), Luke Carrangis (14), Nick Hunt (14), Amy Phillips (14), Carly Starke (14), and Vanessa Walsh (14).

1 Hill D, Willcox S, Gardner G, Houston J. Tobacco and alcohol use among Australian secondary school children. Med F Aust 1987; 146: 125-30. 
2 US Department of Health and Human Services. The health consequences of smoking : nicotine addiction. A report of the Surgeon-General, 1988. Atlanta, Georgia: Centers for Disease Control, Office on Smoking and Health, 1988 DHHS Publication No (CDC) 88-8406.)

3 Leventhal H, Glynn K, Fleming R. Is the smoking decision an 'informed choice'? Effect of smoking risk factors on smoking beliefs. FAMA 1987; 257: 3373-6.

4 Oei TPS, Fae A, Silva P. Smoking behaviour in nine year old children: a replication and extension study. $A d v$ Alcohol Subst Abuse 1990; 8: 85-96.

5 Russell MAH. The nicotine addiction trap: a 40-year entence for four cigarettes. $\mathrm{Br} \mathcal{F}$ Addict 1990; 85: 293-300

6 O'Connor J, Daly M. The smoking habit. Dublin: Gill and MacMillan, 1985.

7 Armstrong BK, de Klerk NH, Shean RE, Dunn DA, Dolin PJ. Influence of education and advertising on the uptake of smoking by children. Med $\mathcal{F}$ Aust $1990 ; 152: 117-24$.
Rush BR, Gliksman L, Brook R. Alcohol availability, Rush BR, Gliksman L, Brook R. Alcohol availability,
alcohol consumption and alcohol related damage. 1 . The alcohol consumption and alcohol related damage. 1. The

9 Kaplan J. The hardest drug: heroin and public policy. Chicago: University of Chicago Press, 1985

10 Altman DG, Foster V, Rasenick-Douss L, Tye J. Reducin the illegal sale of cigarettes to minors. f $A M A 1989 ; 261$ : 80-3.

11 Skretny MT, Cummings KM, Sciandra R, Marshall J. An intervention to reduce the sale of cigarettes to minors. NY State f Med 1990 90: 54-5.

12 Moser CA, Kalton G. Survey methods in social investigation. London: Heineman, 1977.

13 Mawby L, Neill M, Christie P, Cormack S. Survey of alcohol, tobacco and other drug use by South Australian alcohol, tobacco and other drug use by South Australian Alcohol Services Council, Monitoring Evaluation and Research Unit, 1991.
14 Kirn TF, Laws ban minors' tobacco purchases, but enforcement is another matter. $尹 A M A$ 1989; 257: $3323-4$.

15 DiFranza JR, Norwood BD, Garner DW, Tye J. Legislative efforts to protect children from tobacco. $\mathscr{F} A M A 1987$; 257: 3387-9

16 Sullivan LW. Model sale of tobacco products to minors control Act, Secretary of Health and Human Services, Statement to the Committee on Finance, United States Senate, 24 May 1990.

17 United States Department of Health and Human Services. The health consequences of smoking : 25 years of progress. $A$ report of the Surgeon General, 1989. Atlanta, Georgia: report of the Surgeon Geneal, 1989 . Atlanta, Georgia: and Health, 1989. (DHHS Publication No (CDC) $89-8411$.

18 Altman DG, Rasenick-Douss L, Foster V, Tye JB. Sustained effects of an educational program to reduce sales of cigarettes to minors. Am $\mathcal{F}$ Public Health 1991; sales of cigar $891-3$.

19 Porter A. Disciplinary attitudes and cigarette smoking: a comparison of two schools. BMF 1982; 285: 1725-6.

20 Crow CS. Smoking areas on school grounds: are we encouraging teenagers to smoke? f Adolesc Health Car $1984 ; 5: 117-9$

21 Pierce JP, Naquin M, Gilpin E, Giovino G, Mills S, Marcus S. Smoking initiation in the United States: a role for worksite and college smoking bans. 7 Natl Cancer Inst $1991 ; 83: 1009-13$.

22 Jason LA, Ji PY, Anes MD, Birkhead SH. Active enforcement of cigarette control laws in the prevention of cigarette sales to minors. $7 A M A 1991 ; 266: 3159-61$.

23 DiFranza JR, Carlson RP, Caisse RE. Reducing youth access to tobacco. Tobacco Control 1992; $1: 58$.

24 Cummings KM, Sciandra R, Lawrence J. Tobacco ad vertising in retail stores. Public Health Rep 1991; 106 $570-5$.

Venta ilegal de cigarrillos a los niños en Australia Meridional

Melanie Wakefield et al

\section{Resumen}

Objetivo: Evaluar la facilidad con que los niños de Australia Meridional pueden adquirir cigarrillos en las tiendas al detalle y en los distribuidores automáticos.

Diseño: Diez niños de edades entre los 12 y los 14 años visitaron 98 tiendas y 29 distribuidores automáticos con el propósito de adquirir cigarrillos.

Principales evaluaciones obtenidas: Porcentaje de tentativas exitosas para adquirir cigarrillos.

Resultados: Los niños lograron comprar cigarrillos en casi la mitad de las tiendas y en todos los distribuidores automáticos. Esto ocurrió a pesar de que en aproximadamente dos tercios de las tiendas y en tres cuartos de los distribuidores automáticos había avisos que advertian sobre las ventas a menores.

Conclusión: Es necesario implantar controles más efectivos de las ventas al detalle para impedir la compra relativamente fácil de cigarrillos por los niños en Australia Meridional.

目标：分析在澳大利亚儿童从零售店和自动售货机购买卷烟的容易程度。

设计：10名 12-14 岁的儿童到 98 个商店和 29 台自动售货机去买烟。

调查内容: 成功地买到烟的比例

结果：儿童从几乎 $50 \%$ 的商店中成功地买到烟，从占动售货机买到烟的比例是 $100 \%$

结论：在南澳大利亚，应进一步加强卷烟零售的控制，使儿童不易买到烟。

(中国健康教育研究所烟草控制与疾病预防研究室 郑保义译) 